This is a self-archived - parallel published version of this article in the publication archive of the University of Vaasa. It might differ from the original.

\title{
Determinants of voluntary sustainability assurance: the importance of corporate environmental performance
}

\author{
Author(s): Dutta, Probal
}

Title: Determinants of voluntary sustainability assurance: the importance of corporate environmental performance

Year: $\quad 2019$

Version: Accepted manuscript

Copyright C2019 Emerald Publishing Limited. This manuscript version is made available under the Creative Commons Attribution-NonCommercial 4.o International (CC BY-NC 4.0) license, https://creativecommons.org/licenses/by-nc/4.0/

\section{Please cite the original version:}

Dutta, P. (2019). Determinants of voluntary sustainability assurance: the importance of corporate environmental performance. Social Responsibility Journal 16(8), 1403-1414. https://doi.org/10.1108/SRJo6-2019-0213 


\title{
Determinants of Voluntary Sustainability Assurance: The Importance of Corporate Environmental Performance
}

\begin{abstract}
Purpose: The main purpose of this study is to investigate whether corporate environmental performance exerts any significant influence on the voluntary external assurance of sustainability reports.

Design/methodology/approach: The sample of this study includes 176 firm-year observations covering an 8-year period (2008-2015) for 22 listed Finnish companies that have issued sustainability reports during the sample period. As the dependent variable 'voluntary external assurance' is a binary variable, a logistic regression model has been estimated to observe the effect of corporate environmental performance on the dependent variable. In addition, a number of control variables have also been included in the empirical model.
\end{abstract}

Findings: The results of this study exhibit that Finnish firms with superior environmental performance in terms of GHG emissions and water consumption have their sustainability reports externally assured. Additionally, among the control variables, firm size, leverage and asset age are found to have significant impact on the adoption of voluntary sustainability assurance. These results are robust as they do not change substantially when conducting sub-sample analyses.

Originality/value: The literature on voluntary sustainability assurance is evolving slowly paying very little attention to the association between corporate environmental performance and voluntary sustainability assurance. This empirical research aims to extend such scant literature. The results are of paramount importance to users of environmental information, managers and regulators.

Keywords: Voluntary external assurance; Corporate environmental performance; Legitimacy theory; Sustainability reports; Propensity to emit GHG; Propensity to consume water; Propensity to produce waste. 


\section{Introduction}

This study examines the importance of corporate environmental performance (CEP) as a determinant of voluntary external assurance on sustainability reports issued by corporations. Against the backdrop of environmental degradation (e.g., global warming), all kinds of stakeholders (i.e., shareholders and other stakeholders) have become critical of corporations for their role in inflicting damage (through their activities) on the natural environment. Consequently, corporations are increasingly under pressure from these stakeholders to become more environmentally responsive, more serious about sustainable development and more accountable for their decisions and activities affecting the environment; in response to stakeholders' demand for greater accountability for environmental issues, companies are voluntarily and increasingly disclosing different types of environmental information in their sustainability reports (Braam et al., 2016). But prior research (e.g., Braam et al., 2016; Cho \& Patten, 2007; Luo et al., 2012; Cormier et al., 2005) suggests that firms may use environmental reporting (ER) as a communication strategy; for instance, firms with superior CEP may use ER to send signals to their stakeholders about their relatively good CEP. On the other hand, poor environmental performers may use ER to manipulate public perceptions by hiding actual CEP. The potential use of ER as an impression management tool by companies raises concerns about the reliability and credibility of the reported information in corporate sustainability reports (Cho et al., 2012). In the face of the potential loss of stakeholders' confidence in the credibility of the disclosed environmental information, companies are showing a heightened tendency to have their sustainability reports externally assured in order to enhance the credibility of the reported information, restore stakeholders' confidence in the same and thus build corporate reputation (Simnett et al., 2009; Braam et al., 2016; Al-Shaer and Zaman, 2018). 
The existing literature suggests that there are only a few studies on the factors influencing the implementation of voluntary external assurance on sustainability reports (Ruhnke \& Gabriel, 2013; Gillet-Monjarret, 2015; Al-Shaer and Zaman, 2018). In addition, conclusions of the studies investigating the determinants of voluntary sustainability assurance (VSA) are somewhat mixed (Ruhnke and Gabriel, 2013). For instance, Simnett et al. (2009) analyze the sustainability reports produced by 2,113 companies of 31 countries over the period from 2002 to 2004 in order to identify the determinants of VSA and confirm that company-, industry- and country-related factors influence firms' decision to have their sustainability reports externally assured. As regards company and industry-related factors, larger companies belonging to environmentally or socially sensitive industries are more likely to purchase external assurance for their sustainability reports. As far as country-related factors are concerned, companies domiciled in countries that are stakeholder-oriented (code law countries where attention is paid to all stakeholders including shareholders) and have a rigorous legal environment tend strongly to have their sustainability reports externally assured. In contrast to Simnett et al. (2009), Kolk and Perego (2010) find that a company's VSA demand is negatively and significantly associated with the legal environment of the company's country of domicile; the company size is not found to have any significant influence on a company's choice to purchase external assurance as well. However, Kolk and Perego (2010) find a greater demand for VSA in code law countries. Ruhnke and Gabriel (2013) investigate the determinants of external assurance on sustainability reports issued by companies in Germany, the Netherlands and Great Britain and report that companies' decision to purchase VSA is linked with the type and scope of the sustainability reporting, the existence of a sustainability department, and the size of the company. They reveal further that corporate demand for VSA is highest in Great Britain. Gillet-Monjarret (2015) examines the impact of 
media pressure on the implementation of VSA by 120 French listed companies over the period of four years (2007-2010) and finds that media pressure explains the implementation of VSA by companies. Peters and Romi (2015) investigate the impact of sustainability governance characteristics on VSA of listed US companies (from 2002 to 2010). They reveal that the presence of a Chief Sustainability Officer (CSO) on the board of directors is positively linked with the adoption of VSA by US companies. In addition, if the CSO has sustainability expertise the likelihood of adopting VSA increases. Furthermore, companies that have environmental committees consisting of directors with sustainability expertise tend to demand for VSA. AlShaer and Zaman (2018) find that audit committee characteristics such as audit committee independence, number of audit committee meetings and financial expertise of audit committee members have an impact on the adoption of VSA but the size of the audit committee is not associated with the demand for VSA. The preceding discussion on prior research shows the scarcity of studies investigating the association between CEP and VSA. This research, drawing on legitimacy theory, addresses this gap by exploring the association between CEP and VSA and thus contributes to the emerging literature on VSA.

Legitimacy theory posits that companies are members of society and tap into the scarce resources of society (Luo and Tang, 2014). Consequently, it is expected that the actions of companies will be "desirable, proper or appropriate within some socially constructed system of norms, values, beliefs and definitions" (Suchman, 1995, p. 274). In other words, companies are expected to operate within the bounds of an acceptable value system in order to continue its existence in society (Dowling and Pfeffer, 1975; Gray et al., 1995). In case of failure to meet societal expectations on the part of a company, its organizational legitimacy will be threatened and its survival will be in question (Sethi, 1979). According to legitimacy theory, a "social contract" 
exists between companies and the larger social system within which they operate and hence, they will continuously seek to conform to the social contract so that their legitimacy is not threatened (Deegan and Rankin, 1996; Yunus et al., 2016). The growing public attention on environmental issues persuades firms to engage in environmentally responsible practices (K1liç and Kuzey, 2019). In order to keep the social contract intact and maintain legitimacy, firms need to inform society in general that they are taking their environmental responsibilities seriously (Yunus et al., 2016) and one way of doing this is to disclose information about their environmentally responsible practices via sustainability reports (Kılıç and Kuzey, 2019). Gillet-Monjarret (2015) contends that since independent assurance legitimizes the actions of the company, organizational legitimacy is strengthened further if the reliability of the information disseminated via corporate sustainability reports is ensured by an independent assurance provider. Kolk and Perego (2010) add further that companies are adopting VSA for obtaining legitimacy and their assertion is reflected in the increased number of businesses implementing VSA over the years (O'Dwyer and Owen, 2005). The standing literature suggests that both superior and inferior environmental performers tend to provide information about their EP on two different grounds. Firms with good EP voluntarily disclose information about their performance in order to distinguish themselves from firms with poor EP and thus avoid the problem of adverse selection (Belkaoui and Karpik, 1989; Clarkson et al., 2008; Luo and Tang, 2014). This argument is in line with voluntary disclosure theory (Clarkson et al., 2008; Luo and Tang, 2014; Giannarakis et al., 2017). On the other hand, poor environmental performers face threatened organizational legitimacy. As a legitimacy repairing strategy, firms with poor EP make increased discretionary environmental disclosures so that public perceptions about their actual EP are changed (Clarkson et al., 2008; Luo and Tang, 2014). This argument is consistent with the premise of legitimacy theory 
(Clarkson et al., 2008; Luo and Tang, 2014; Giannarakis et al., 2017). Irrespective of their 'EP type', firms tend to have their sustainability reports externally assured as assurance establishes the reliability and enhances the credibility of the reported environmental information (Simnett $e t$ al., 2009; Moroney et al., 2012; Gillet-Monjarret, 2015; Braam et al., 2016).

Given that both superior and inferior environmental performers tend to provide environmental disclosures and seek to establish the reliability and improve the credibility of the disseminated information, it is expected that an association between CEP and VSA exists and hence, the following non-directional hypothesis is formulated:

Hypothesis: Corporate environmental performance has a significant impact on voluntary external assurance of sustainability reports.

The remainder of the paper is organized as follows. The next section describes the sample and methodology used. The results are presented and discussed in section three. Finally, section four concludes the paper.

\section{Methods}

\subsection{Sample and data}

The sample of this study includes 176 firm-year observations covering an 8-year period (20082015) for 22 listed Finnish companies that have issued sustainability reports during the sample period. The availability of data dictates the sample size and the sample period. Finland has been used as the research context because of the country's strong commitment to sustainable development. Finland is one of the forerunners to implement the 'UN 2030 Agenda for 
Sustainable Development'. The 'UN 2030 Agenda for Sustainable Development' aims at ensuring sustainable development in all dimensions: economy, the environment and well-being. ${ }^{2}$ The UN 2030 Agenda includes 17 goals and 169 targets; there are 200 global indicators supplemented by national indicators of individual countries for monitoring progress. Finland is not only one of the first countries to put in place national objectives, actions and a monitoring and assessment system for attaining the goals of the UN, but also an active participant in the international monitoring of the UN 2030 Agenda. At the national level, Finland has introduced 'Society's Commitment to Sustainable Development', a key instrument for implementing the UN 2030 Agenda through which the state along with other actors in society such as local governments, companies, corporations, civil society and citizens can contribute to the implementation of the world's common development plan. ${ }^{3}$ Finland is also committed to assume global responsibility to extend the effect of this contribution beyond its national borders. In this empirical research, data on external assurance are retrieved from the sustainability reports of the sampled firms and firm-specific data are extracted from Thomson Reuters DataStream database.

\subsection{Variables}

\subsubsection{Dependent variable}

Voluntary sustainability assurance is the binary dependent variable that takes a value of 1 if the corporate sustainability report is externally assured and 0 otherwise (Simnett et al., 2009; Kolk \& Perego, 2010; Ruhnke \& Gabriel, 2013; Gillet-Monjarret, 2015; Braam et al., 2016; Al-Shaer \& Zaman, 2018).

\footnotetext{
${ }^{1}$ This information is sourced from the website https://um.fi/agenda-2030-sustainable-development-goals\#inFinland.

${ }^{2}$ This information is sourced from the website https://um.fi/documents/35732/0/UAM_Kesta\%CC\%88va\%CC\%88kehitys_A4_EN_18102018\%20\%281\%29.pdf/1a236110-e890-85e2-1aea-e68b2a9df486?t=1540750202357.

${ }^{3}$ This information is sourced from the website https://kestavakehitys.fi/en/commitment2050.
} 


\subsubsection{Independent variable}

CEP appears to be the only independent variable in this study. As suggested by previous research (Al-Tuwaijari et al., 2004; Cho and Patten, 2007; Clarkson et al., 2008; Luo and Tang, 2014; Braam et al., 2016), scaled measures of CEP have been used. These measures include (i) the ratio of total greenhouse gas (GHG) emissions to total revenue (or propensity to emit GHG), (ii) the ratio of waste production to total revenue (or propensity to produce waste) and (iii) the ratio of water consumption to total revenue (or propensity to consume water) (Braam et al., 2016). Higher propensities imply increased amount of GHG emissions, waste production and water consumption and thereby inferior EP (Clarkson et al., 2011). Scaled measures of CEP have edge over absolute measures of CEP (e.g., the total amount of water consumed) because scaled measures consider variations in the output of products and services (Luo and Tang, 2014) and thus facilitate comparisons of EP across companies and between different periods (Hoffmann and Busch, 2008).

\subsubsection{Control variables}

Consistent with previous studies, this paper controls for the effect of a number of variables namely, firm size (FSIZE), profitability (PROF), leverage (LEV), industry (IND) and asset age (ASST_AGE). Larger companies are more visible and subject to greater social pressure to operate in an environmentally responsible way (Patten, 2002a; Gonzalez-Gonzalez and Ramírez, 2016). This will, according to legitimacy theory, lead them to make a higher level of disclosures about their EP to avoid legitimacy threat (Mobus, 2005) and hence they are more likely to purchase VSA to increase the reliability and credibility of the reported information. Hence a positive association between FSIZE and VSA is expected. FSIZE is calculated as the natural 
logarithm of year-end total assets (Gillet-Monjarret, 2015; Ruhnke \& Gabriel, 2013; Jaggi et al., 2018; Al-Shaer and Zaman, 2018). More profitable companies are financially more capable of making sustainability decisions such as sustainability investments and purchase of sustainability assurance (Ruhnke \& Gabriel, 2013). Therefore, a positive linkage between PROF and VSA is anticipated. PROF is measured by the return-on-assets (ROA), which is calculated as the ratio of year-end net income to year-end total assets (Ruhnke \& Gabriel, 2013; Gillet-Monjarret, 2015; Peters and Romi, 2015; Al-Shaer and Zaman, 2018). Given that the relationship between LEV and VSA is inconclusive (Simnett et al., 2009; Ruhnke \& Gabriel, 2013; Gillet-Monjarret, 2015; Peters and Romi, 2015; Al-Shaer and Zaman, 2018), it is not possible to anticipate whether LEV and VSA are positively or negatively linked (Ruhnke \& Gabriel, 2013). Therefore, only a significant association between LEV and VSA is assumed. Debt-equity ratio is used as the proxy for LEV (Jaggi et al., 2018). Firms belonging to environmentally sensitive (ES) industries face greater public pressures related to environmental issues (Kolk and Perego, 2010; GilletMonjarret, 2015; Peters and Romi, 2015) and respond to such pressures by providing sustainability information (Gillet-Monjarret, 2015). In order to offer reliability and credibility to their sustainability information, ES firms tend to purchase VSA (Kolk and Perego, 2010; GilletMonjarret, 2015; Peters and Romi, 2015). Following prior studies (Patten, 2002b; Clarkson et al., 2008; Cho et al., 2014; Yunus et al., 2016), energy, utilities, transportation, pharmaceuticals, materials, mining and extractive, paper, chemicals, petroleum, metals, utilities and telecommunication industries are considered ES industries. IND is a dummy variable taking a value of 1 for ES firms and 0 otherwise (Cho et al., 2014; Yunus et al., 2016). Finally, this study controls for ASST_AGE as firms investing in newer and cleaner technologies are likely to cause less environmental pollution and tend to inform their stakeholders of such fact through increased 
environmental disclosures (Clarkson et al., 2008; Moroney et al., 2012). In order to increase stakeholders' confidence in their sustainability reports, they are also likely to implement VSA. Consequently, a positive relationship is expected between ASST_AGE and VSA. ASST_AGE is measured as the ratio of net properties, plant and equipment to gross properties, plant and equipment (Clarkson et al., 2008).

\subsection{Regression model}

To test the proposed hypothesis, the following pooled logistic regression models are estimated:

$V S A=\beta_{0}+\beta_{1} C E P_{1}+\beta_{2} C E P_{3}+\beta_{3} F S I Z E+\beta_{4} P R O F+\beta_{5} L E V+\beta_{6} I N D+\beta_{7} A S S T \_A G E+\varepsilon_{1}(1)$

$V S A=\beta_{0}+\beta_{1} C E P_{2}+\beta_{2} C E P_{3}+\beta_{3} F S I Z E+\beta_{4} P R O F+\beta_{5} L E V+\beta_{6} I N D+\beta_{7} A S S T \_A G E+\varepsilon_{2}(2)$

where $V S A=$ voluntary sustainability assurance $C E P=$ corporate environmental performance $\left(\mathrm{CEP}_{1}=\right.$ the ratio of total $\mathrm{GHG}$ emitted to total revenue; $\mathrm{CEP}_{2}=$ the ratio of total water consumed to total revenue; $\mathrm{CEP}_{3}=$ the ratio of total waste produced to total revenue); FSIZE = firm size; $P R O F=$ profitability; $L E V=$ leverage; $I N D=$ industry; $A S S T \_A G E=$ asset age. Table 1 provides the summary of the variables used in this study.

Table 2 presents the Pearson correlations coefficients for the variables used in this study. According to Gujarati (1995), multicollinearity exists if the value of the correlation coefficient between two independent variables exceeds 0.80. Table 2 shows a correlation of 0.955721 between $\mathrm{CEP}_{1}$ and $\mathrm{CEP}_{2}$. On the other hand, the correlations among other independent and/or control variables are less than 0.50 . This clearly indicates the existence of multicollinearity between $\mathrm{CEP}_{1}$ and $\mathrm{CEP}_{2}$. In addition, the variance inflation factor $(\mathrm{VIF})$ between $\mathrm{CEP}_{1}$ and $\mathrm{CEP}_{2}$ amounts to 10.42 which also confirms the presence of multicollinearity between these two 
measures of corporate environmental performance. As a result, it is not possible to accommodate all three proxies for CEP in a single model.

\section{Results and Discussion}

\subsection{Descriptive statistics}

Table 3 presents descriptive statistics for the total sample. The mean of VSA is 0.57 indicating that about $57 \%$ of the sustainability reports have been externally assured. As far as CEP measures are concerned, a considerable variation is seen in cases of $\mathrm{CEP}_{1}$ and $\mathrm{CEP}_{2}$. For example, the mean of $\mathrm{CEP}_{1}$ is 0.48 with minimum and maximum of 0.01 and 5.60 respectively; the mean of $\mathrm{CEP}_{2}$ is 46.44 with minimum and maximum of 0.01 and 618.52 respectively. On the other hand, $\mathrm{CEP}_{3}$ has a mean of 0.07 with minimum and maximum 0.00 and 0.58 , respectively. LEV has a mean of 0.47 and PROF has a mean of 0.05 . The mean of FSIZE is 6.69 with minimum and maximum of 5.68 and 7.58 respectively implying that the sample includes both medium and large firms. The mean of IND is 0.77 revealing that around $77 \%$ of the sampled firms belong to environmentally sensitive industries. The mean of ASST_AGE is 0.43 indicating that firms are in possession of older assets.

\subsection{Regression results}

The regression results are presented in Table 4. Two different models have been estimated to observe the impact of CEP on the adoption of VSA. In Model 1, CEP is measured as the ratios of total GHG emissions to total revenues $\left(\mathrm{CEP}_{1}\right)$ and total waste produced to total revenues $\left(\mathrm{CEP}_{3}\right)$; whereas in Model 2, the ratios of total water consumed to total revenues $\left(\mathrm{CEP}_{2}\right)$ and $\mathrm{CEP}_{3}$ are used as the indicators of CEP. 
Model 1 demonstrates that $\mathrm{CEP}_{1}$ is negatively and significantly linked to VSA $(p<0.01)$ indicating that firms with better environmental performance (EP) in terms of GHG emissions tend to demand for VSA. In addition, FSIZE, a firm-specific control variable, has a significant and positive relationship with VSA $(p<0.01)$ suggesting that larger firms are more likely to implement VSA. $\mathrm{CEP}_{3}$ and the remaining firm-specific control variables are found to have no linkage with VSA.

Model 2 exhibits a highly significant inverse relationship between $\mathrm{CEP}_{2}$ and VSA $(p<0.01)$ but $\mathrm{CEP}_{3}$ is still found to be insignificant suggesting that firms with better EP in terms of water consumption have a tendency to demand for VSA. In addition, except PROF and IND, other firm-specific control variables are found to be significant at different conventional levels of significance. For instance, FSIZE, ASST_AGE and LEV are statistically significant at 1\%, 5\% and $10 \%$ respectively, which indicates that larger firms, firms with less polluting new assets and low-leverage firms are more inclined to have their sustainability reports externally assured. Model 2 also shows an improvement in the model fit ( $\mathrm{R}^{2}$ improves from 0.30 to 0.43 ).

Overall, these findings provide support for the proposed hypothesis that corporate environmental performance influences the adoption of voluntary assurance of sustainability reports. GilletMonjarret (2015) asserts that corporate legitimacy can be strengthened if independent assurance providers recognize the reliability of the environmental information provided in corporate sustainability reports. Therefore, the results of this study are supportive of legitimacy theory suggesting that superior environmental performers (companies with lower propensity to emit GHG and consume water in this research) show their commitment to maintain and protect the natural environment through disclosures of reliable information about their relatively good EP in sustainability reports and thus maintain legitimacy. The robustness of legitimacy theory is also 
confirmed by the significant and positive FSIZE-VSA nexus as well as ASST_AGE-VSA nexus. Larger firms, due to their higher visibility and greater public scrutiny, are subject to external pressure to report information about their EP; consequently, they are likely to disclose more environmental information (Yunus et al., 2016; K1liç and Kuzey, 2019). In addition, firms with newer and less polluting assets are likely to voluntarily provide more environmental information to send signals to the market and society in general about their seriousness towards environmental responsibilities (Clarkson et al., 2008; Moroney et al., 2012). In both cases, disclosing firms are likely to obtain VSA to increase the reliability and credibility of the reported information and thus strengthen the legitimacy of their continued existence in society (Deegan and Gordon, 1996). A plausible explanation why the propensity to produce waste does not affect the adoption of VSA may be that Finnish companies may not yet consider the generation of waste an important indicator of EP.

\subsection{Robustness check}

For robustness check, sub-sample analyses have been conducted. In doing so, the whole sample has been split into two subsamples: the first subsample covers the period from 2008 to 2011, while the second one spans from 2012 to 2015. The results of the subsample analysis are presented in Tables 5 and 6 . These findings mirror those reported in Table 4. For instance, $\mathrm{CEP}_{1}$ and $\mathrm{CEP}_{2}$ remain highly significant at conventional levels indicating that these measures have emerged as the main determinants of VSA irrespective of the time periods used. However, few discrepancies are also observed. For example, while $\mathrm{CEP}_{3}$ is found to have no impact on VSA when performing the full period analysis, it has now become significant at 10\% level in Model 2.

Besides, for each sub-sample, the $\mathrm{R}^{2}$ statistic improves substantially. To sum up, the results of 
this empirical research are quite robust as they do not change substantially depending on the time periods considered.

\section{Conclusions, Implications and Limitations}

This study advances the literature on voluntary sustainability assurance, which is considered important for establishing the reliability and enhancing the credibility of the environmental information disclosed in corporate sustainability reports and thus strengthening organizational legitimacy. The literature on voluntary sustainability assurance is evolving slowly paying very little attention to the relationship between corporate environmental performance and voluntary sustainability assurance. This empirical work provides initial evidence of the impact of corporate environmental performance on the implementation of voluntary assurance of corporate sustainability reports. Drawing on legitimacy theory, the association between different measures (propensities to emit GHG, consume water and produce waste) of corporate environmental performance and the adoption of voluntary sustainability assurance is tested.

The results of this study exhibit that Finnish firms with superior environmental performance in terms of GHG emissions and water consumption have their sustainability reports externally assured. Conforming to legitimacy theory the findings suggest that superior environmental performers provide information about their environmental performance in sustainability reports with a view to showing their commitment to environmental protection, increase the reliability and credibility of the disclosed environmental performance information by adopting voluntary sustainability assurance and thus strengthen organizational legitimacy.

The findings of this study have implications for users of environmental information, managers and regulators. The results will enable users of environmental information to judge the reliability 
and credibility of the information (disseminated via corporate sustainability reports) about corporate environmental performance of reporting firms. The external assurance reduces corporate management's opportunity to utilize environmental reporting as a management tool to divert public attention from actual environmental performance and hence restores environmental information users' confidence in the credibility of sustainability reports. On the other hand, corporate managers will be benefited from the findings of this research by paying attention to the provision of reliable environmental information to relevant publics. The supply of reliable information to relevant publics will keep them informed that companies are operating within the bounds of an acceptable value system. This will help companies maintain legitimacy and ensure their continued existence in society. Finally, the results will be important for regulators, who may keep an eye on the transparency of firms' voluntary environmental disclosures. In case companies fail to provide reliable and credible information about their environmental performance, regulators may develop stringent rules and regulations for complementing voluntary sustainability assurance by mandatory requirements for sustainability disclosures and assurance.

This research is subject to certain limitations. First, it is not likely that all companies use the same method for measuring their environmental performance and hence the measures of corporate environmental performance used in this research may not be exhaustive. In addition, the estimated models may not have included all the control variables that can affect the adoption of voluntary sustainability assurance. Second, the sample includes only the companies that have published sustainability reports. Third, this research is based solely upon Finnish data, which may inhibit the generalization of the findings in other contexts but this limitation can be overcome in future research by utilizing bigger samples that will include both local and 
international firms to provide greater understanding of how corporate environmental performance affects the adoption of voluntary sustainability assurance. Furthermore, countryspecific studies can also be conducted to facilitate the comparisons of findings.

\section{References}

Al-Shaer, H. \& Zaman, M. 2018. Credibility of sustainability reports: the contribution of audit committees. Business Strategy and the Environment, 27 (7): 973-986.

Al-Tuwaijri, S.A., Christensen, T.E. \& Hughes II, K.E. 2004. The relations among environmental disclosure, environmental performance, and economic performance: a simultaneous equations approach. Accounting, Organizations and Society, 29 (5-6): 447-471.

Belkaoui, A. \& Karpik, P.G. 1989. Determinants of the corporate decision to disclose social information. Accounting, Auditing \& Accountability Journal, 2 (1): 36-51.

Braam, G. J. M., Weerd, L. U. de, Hauck, M. \& Huijbregts, M. A. J. 2016. Determinants of corporate environmental reporting: the importance of environmental performance and assurance. Journal of Cleaner Production, 129: 724-734.

Cho, C.H. \& Patten, D.M. 2007. The role of environmental disclosures as tools of legitimacy: a research note. Accounting, Organizations and Society, 32 (7-8): 639-647.

Cho, C.H., Guidry, R.P., Hageman, A.M. \& Patten, D.M. 2012. Do actions speak louder than words? An empirical investigation of corporate environmental reputation. Accounting, Organizations and Society, 37 (1): 14-25. 
Cho, C. H., Michelon, G., Patten, D. M. \& Roberts, R. W. 2014. CSR report assurance in the USA: an empirical investigation of determinants and effects. Sustainability Accounting, Management and Policy Journal, 5 (2): 130-148.

Clarkson, P.M., Li, Y., Richardson, G.D. \& Vasvari, F.P. 2008. Revisiting the relation between environmental performance and environmental disclosure: an empirical analysis. Accounting, Organizations and Society, 33 (4-5): 303-327.

Clarkson, P.M., Overell, M. B. \& Chapple, L. 2011. Environmental reporting and its relation to corporate environmental performance. Abacus, 47 (1): 27-60.

Cormier, D., Magnan, M. \& Van Velthoven, B. 2005. Environmental disclosure quality in large German companies: economic incentives, public pressures or institutional conditions? European Accounting Review, 14 (1): 3-39.

Deegan, C. \& Gordon, B. 1996. A study of the environmental disclosure practices of Australian corporations. Accounting and Business Research, 26 (3): 187-199.

Deegan, C. \& Rankin, M. 1996. Do Australian companies report environmental news objectively? Accounting, Auditing and Accountability Journal, 9 (2): 50-67.

Dowling, J. \& Pfeffer, J. 1975. Organizational legitimacy: Societal values and organizational behaviour. Pacific Sociological Review, 18 (1): 122-136.

Giannarakis, G., Zafeiriou, E. \& Sariannidis, N. 2017. The Impact of Carbon Performance on Climate Change Disclosure. Business Strategy and the Environment, 26 (8): 1078-1094.

Gillet-Monjarret, C. 2015. Assurance of sustainability informaiton: a study of media pressure. Accounting in Europe, 12 (1): 87-105. 
Gonzalez-Gonzalez, J. M., \& Ramírez, C. Z. 2016. Voluntary carbon disclosure by Spanish companies: an empirical analysis. International Journal of Climate Change Strategies and Management, 8 (1): 57-79.

Gray, R., Kouhy, R. \& Lavers, S. 1995. Corporate social and environmental reporting: A review of the literature and a longitudinal study of UK disclosure. Accounting, Auditing \& Accountability Journal, 8(2): 47-77.

Guajarati D.N. 1995. Basic Econometrics. McGraw-Hill: New York.

Hoffmann, V.H. \& Busch, T. 2008. Corporate carbon performance indicators: carbon intensity, dependency, exposure, and risk. Journal of Industrial Ecology, 12 (4): 505-520.

Jaggi, B., Allini, A., Macchioni, R. \& Zagaria, C. 2018. The Factors Motivating Voluntary Disclosure of Carbon Information: Evidence Based on Italian Listed Companies. Organization \& Environment, 31(2): 178-202.

Kılıç, M. \& Kuzey, C. 2019. The effect of corporate governance on carbon emission disclosures: Evidence from Turkey. International Journal of Climate Change Strategies and Management, 11 (1): 35-53.

Kolk A. \& Perego, P. 2010. Determinants of the adoption of sustainability assurance statements: an international investigation. Business Strategy and the Environment, 19 (3):182-198.

Luo, L., Lan, Y.C. \& Tang, Q. 2012. Corporate incentives to disclose carbon information: evidence from the CDP Global 500 Report. Journal of International Financial Management \& Accounting, 23 (2): 93-120. 
Luo, L. \& Tang, Q. 2014. Does voluntary carbon disclosure reflect underlying carbon performance? Journal of Contemporary Accounting \& Economics, 10 (3): 191-205.

Mobus, J.L. 2005. Mandatory environmental disclosures in a legitimacy theory context. Accounting, Auditing \& Accountability Journal, 18 (4): 492-517.

Moroney, R., Windsor, C. \& Aw, Y.T. 2012. Evidence of assurance enhancing the quality of voluntary environmental disclosures: an empirical analysis. Accounting and Finance, 52 (3): 903-939.

O’Dwyer, B. \& Owen, D. L. 2005. Assurance statement practice in environmental, social and sustainability reporting: A critical evaluation. The British Accounting Review, 37(2): 205-229.

Patten, D.M. 2002a. Media exposure, public policy pressure, and environmental disclosure: an examination of the impact of TRI Data availability. Accounting Forum, 26 (2): 152-171.

Patten, D. M. 2002b. The relation between environmental performance and environmental disclosure: A research note. Accounting, Organizations and Society, 27 (8): 763-773.

Peters, G. F. \& Romi, A. M. 2015. The association between sustainability governance characteristics and the assurance of corporate sustainability reports. Auditing: A Journal of Practice \& Theory, 34 (1): 163-198.

Ruhnke, K. \& Gabriel, A. 2013. Determinants of voluntary assurance on sustainability reports: an empirical analysis. Journal of Business Economics, 83 (9): 1063-1091.

Sethi, S. 1979. A conceptual framework for environmental analysis of social issues and evaluation of business response patterns. Academy of Management Review, 4 (1): 63-74. 
Simnett, R., Vanstraelen, A. \& Chua, W. F. 2009. Assurance on sustainability reports: an international comparison. The Accounting Review, 84 (3): 937-967.

Suchman, M.C. 1995. Managing legitimacy: strategic and institutional approaches. The Academy of Management Review, 20 (3): 571-610.

Yunus, S., Elijido-Ten, E. \& Abhayawansa, S. 2016. Determinants of carbon management strategy adoption: evidence from Australia's top 200 publicly listed firms. Managerial Auditing Journal, 31 (2): 156-179. 
Table 1: Definitions of the variables used

\begin{tabular}{ll}
\hline Variable & Definition \\
\hline VSA & $\begin{array}{l}\text { A dummy variable which takes the value of } 1 \text { if the corporate sustainability report is } \\
\text { externally assured and } 0 \text { otherwise. }\end{array}$ \\
$\mathrm{CEP}_{1}$ & The ratio of total GHG emitted to total revenue. \\
$\mathrm{CEP}_{2}$ & The ratio of total water consumed to total revenue. \\
$\mathrm{CEP}_{3}$ & The ratio of total waste produced to total revenue. \\
FSIZE & The natural logarithm of the company's year-end total assets. \\
PROF & $\begin{array}{l}\text { Return on assets measured by dividing the year-end net income by the year-end total } \\
\text { assets. }\end{array}$ \\
LEV & $\begin{array}{l}\text { Debt-equity ratio measured by dividing total liabilities by total shareholders' equity. } \\
\text { AND }\end{array}$ \\
& $\begin{array}{l}\text { A dummy variable which takes the value of } 1 \text { if the company operates in an } \\
\text { environmentally sensitive industry and } 0 \text { otherwise. }\end{array}$ \\
ASST_AGE & $\begin{array}{l}\text { Measured by dividing net properties, plant and equipment by gross properties plant and } \\
\text { equipment. }\end{array}$ \\
\hline
\end{tabular}


Table 2: Pearson correlations

\begin{tabular}{|c|c|c|c|c|c|c|c|c|c|}
\hline & VSA & $\mathrm{CEP}_{1}$ & $\mathrm{CEP}_{2}$ & $\mathrm{CEP}_{3}$ & FSIZE & PROF & LEV & IND & ASST_AGE \\
\hline VSA & 1.000000 & & & & & & & & \\
\hline $\mathrm{CEP}_{1}$ & $\begin{array}{r}-0.040849 \\
(0.668)\end{array}$ & 1.000000 & & & & & & & \\
\hline $\mathrm{CEP}_{2}$ & $\begin{array}{r}-0.049241 \\
(0.605)\end{array}$ & $\begin{array}{r}0.955721 \\
\quad(0.000)\end{array}$ & 1.000000 & & & & & & \\
\hline $\mathrm{CEP}_{3}$ & $\begin{array}{r}0.301587 \\
(0.001)\end{array}$ & $\begin{array}{r}0.238503 \\
\quad(0.011)\end{array}$ & $\begin{array}{r}0.254024 \\
(0.007)\end{array}$ & 1.000000 & & & & & \\
\hline FSIZE & $\begin{array}{r}0.480907 \\
(0.000)\end{array}$ & $\begin{array}{r}0.413395 \\
\quad(0.000)\end{array}$ & $\begin{array}{r}0.430682 \\
(0.000)\end{array}$ & $\begin{array}{r}0.381817 \\
(0.000)\end{array}$ & 1.000000 & & & & \\
\hline PROF & $\begin{array}{r}-0.241136 \\
(0.110)\end{array}$ & $\begin{array}{r}0.147061 \\
(0.120)\end{array}$ & $\begin{array}{r}0.196042 \\
(0.037)\end{array}$ & $\begin{array}{r}-0.229287 \\
(0.015)\end{array}$ & $\begin{array}{r}-0.025959 \\
(0.785)\end{array}$ & 1.000000 & & & \\
\hline LEV & $\begin{array}{r}0.056238 \\
(0.554)\end{array}$ & $\begin{array}{r}0.186165 \\
(0.048)\end{array}$ & $\begin{array}{r}0.192651 \\
(0.041)\end{array}$ & $\begin{array}{r}0.391599 \\
(0.000)\end{array}$ & $\begin{array}{r}0.148350 \\
(0.117)\end{array}$ & $\begin{array}{r}-0.483101 \\
(0.000)\end{array}$ & 1.000000 & & \\
\hline IND & $\begin{array}{r}-0.011639 \\
(0.903)\end{array}$ & $\begin{array}{r}0.235478 \\
(0.012)\end{array}$ & $\begin{array}{r}0.195521 \\
(0.038)\end{array}$ & $\begin{array}{r}0.283016 \\
(0.002)\end{array}$ & $\begin{array}{r}-0.083723 \\
(0.378)\end{array}$ & $\begin{array}{r}-0.096494 \\
(0.309)\end{array}$ & $\begin{array}{r}0.253414 \\
(0.007)\end{array}$ & 1.000000 & \\
\hline ASST_AGE & $\begin{array}{r}0.109114 \\
(0.250)\end{array}$ & $\begin{array}{r}0.471873 \\
\quad(0.000)\end{array}$ & $\begin{array}{r}0.471209 \\
(0.000)\end{array}$ & $\begin{array}{r}-0.140997 \\
(0.136)\end{array}$ & $\begin{array}{r}0.129303 \\
(0.172)\end{array}$ & $\begin{array}{r}0.067691 \\
(0.476)\end{array}$ & $\begin{array}{r}-0.189806 \\
(0.044)\end{array}$ & $\begin{array}{r}-0.065007 \\
(0.494)\end{array}$ & 1.000000 \\
\hline
\end{tabular}

Note: $V S A=$ voluntary sustainability assurance; $C E P=$ corporate environmental performance $\left(\mathrm{CEP}_{1}=\right.$ the ratio of total GHG emitted to total revenue; $\mathrm{CEP}_{2}=$ the ratio of total water consumed to total revenue; $\mathrm{CEP}_{3}=$ the ratio of total waste produced to total revenue); $F S I Z E=$ firm size; $P R O F=$ profitability; $L E V=$ leverage; $I N D=$ industry; $A S S T \_A G E=$ asset age; $p$-values are given in parentheses. 
Table 3: Descriptive statistics

\begin{tabular}{lcccc}
\hline \multicolumn{1}{l}{ Total sample $(\mathrm{N}=176)$} & \multicolumn{3}{l}{} \\
\hline Variable & Mean & Maxi. & Min. & Std. Dev. \\
VSA & 0.57 & & & 0.50 \\
CEP $_{1}$ & 0.48 & 5.60 & 0.01 & 1.05 \\
CEP $_{2}$ & 46.44 & 618.52 & 0.01 & 128.14 \\
CEP $_{3}$ & 0.07 & 0.58 & 0.00 & 0.13 \\
FSIZE & 6.69 & 7.58 & 5.68 & 0.43 \\
PROF & 0.05 & 0.20 & -0.09 & 0.06 \\
LEV & 0.47 & 2.21 & 0.02 & 0.31 \\
IND & 0.77 & & & 0.42 \\
ASST_AGE & 0.43 & 0.70 & 0.20 & 0.12
\end{tabular}

Note: $V S A=$ voluntary sustainability assurance; $C E P=$ corporate environmental performance $\left(\mathrm{CEP}_{1}=\right.$ the ratio of total GHG emitted to total revenue; $\mathrm{CEP}_{2}=$ the ratio of total water consumed to total revenue; $\mathrm{CEP}_{3}=$ the ratio of total waste produced to total revenue); $F S I Z E=$ firm size; $P R O F=$ profitability; $L E V$ $=$ leverage; $I N D=$ industry; $A S S T \_A G E=$ asset age. 
Table 4: Regression results for the full sample

\begin{tabular}{|c|c|c|c|c|c|}
\hline \multicolumn{6}{|c|}{ Dependent variable VSA } \\
\hline \multirow[t]{2}{*}{ Variable } & \multirow[t]{2}{*}{ Expected Sign } & \multicolumn{2}{|c|}{ Model 1} & \multicolumn{2}{|c|}{ Model 2} \\
\hline & & Coefficient & Standard Error & Coefficient & Standard Error \\
\hline Intercept & & $-28.29 * * *$ & 6.12 & $-31.68 * * *$ & 7.06 \\
\hline $\mathrm{CEP}_{1}$ & $+/-$ & $-1.05 * * *$ & 0.33 & & \\
\hline $\mathrm{CEP}_{2}$ & $+/-$ & & & $-0.01 * * *$ & 0.004 \\
\hline $\mathrm{CEP}_{3}$ & $+/-$ & 1.46 & 3.03 & 17.45 & 11.83 \\
\hline FSIZE & + & $4.13 * * *$ & 0.90 & $4.46^{* * *}$ & 0.99 \\
\hline PROF & + & -5.76 & 4.98 & -10.48 & 6.90 \\
\hline LEV & $+/-$ & -0.30 & 0.91 & $-2.20 *$ & 1.21 \\
\hline IND & + & 0.57 & 0.66 & 0.92 & 0.76 \\
\hline ASST_AGE & + & 3.47 & 2.40 & $7.51 * *$ & 3.04 \\
\hline $\mathrm{R}^{2}$ & & & & & \\
\hline LR statistic & & & & & \\
\hline Prob (LR statistic) & & & & & \\
\hline
\end{tabular}


Table 5: Regression results for sub-sample I

\begin{tabular}{|c|c|c|c|c|c|}
\hline \multicolumn{6}{|c|}{ Dependent variable VSA } \\
\hline \multirow[t]{2}{*}{ Variable } & \multirow[t]{3}{*}{ Expected Sign } & \multicolumn{2}{|c|}{ Model 1} & \multicolumn{2}{|c|}{ Model 2} \\
\hline & & Coefficient & Standard Error & Coefficient & Standard Error \\
\hline Intercept & & $-28.38 * * *$ & 10.39 & $-35.97 * * *$ & 11.92 \\
\hline $\mathrm{CEP}_{1}$ & $+/-$ & $-1.45^{* *}$ & 0.57 & & \\
\hline $\mathrm{CEP}_{2}$ & $+/-$ & & & $-0.02 * * *$ & 0.01 \\
\hline $\mathrm{CEP}_{3}$ & $+/-$ & 4.55 & 3.54 & $20.37 *$ & 12.34 \\
\hline FSIZE & + & $3.70 * * *$ & 1.36 & $4.42 * * *$ & 1.49 \\
\hline PROF & + & -4.90 & 7.52 & -6.83 & 8.92 \\
\hline LEV & $+/-$ & -2.94 & 1.89 & $-5.51 *$ & 2.98 \\
\hline IND & + & 1.26 & 1.37 & 2.23 & 1.49 \\
\hline ASST_AGE & + & $10.45 * *$ & 4.47 & $17.33 * * *$ & 6.29 \\
\hline $\mathrm{R}^{2}$ & & & & & \\
\hline LR statistic & & & & & \\
\hline Prob (LR statistic) & & & & & \\
\hline
\end{tabular}

Note: This table presents the results for sub-sample I which covers the period from 2008 to 2011. VSA = voluntary sustainability assurance; $C E P=$ corporate environmental performance $\left(\mathrm{CEP}_{1}=\right.$ the ratio of total $\mathrm{GHG}$ emitted to total revenue; $\mathrm{CEP}_{2}=$ the ratio of total water consumed to total revenue; $\mathrm{CEP}_{3}=$ the ratio of total waste produced to total revenue); FSIZE = firm size; $P R O F=$ profitability; $L E V=$ leverage; $I N D=$ industry; $A S S T \_A G E=$ asset age. $* * * \mathrm{p}<0.01 ; * * \mathrm{p}<0.05 ; * \mathrm{p}<0.10$. 
Table 6: Regression results for sub-sample II

\begin{tabular}{|c|c|c|c|c|c|}
\hline \multicolumn{6}{|c|}{ Dependent variable VSA } \\
\hline \multirow[t]{2}{*}{ Variable } & \multirow[t]{3}{*}{ Expected Sign } & \multicolumn{2}{|c|}{ Model 1} & \multicolumn{2}{|c|}{ Model 2} \\
\hline & & Coefficient & Standard Error & Coefficient & Standard Error \\
\hline Intercept & & $-70.61 * * *$ & 26.52 & $-111.92 * *$ & 56.51 \\
\hline $\mathrm{CEP}_{1}$ & $+/-$ & $-2.49^{*}$ & 1.38 & & \\
\hline $\mathrm{CEP}_{2}$ & $+/-$ & & & $-0.04 * *$ & 0.02 \\
\hline $\mathrm{CEP}_{3}$ & $+/-$ & 47.27 & 35.95 & $133.80^{*}$ & 69.82 \\
\hline FSIZE & + & $11.54 * * *$ & 4.37 & $19.58^{*}$ & 10.02 \\
\hline PROF & + & $-24.16^{*}$ & 12.84 & $-78.34 *$ & 44.07 \\
\hline LEV & $+/-$ & 0.68 & 1.98 & $-6.81 *$ & 3.63 \\
\hline IND & + & -0.09 & 1.30 & -1.58 & 2.54 \\
\hline ASST_AGE & + & -7.44 & 7.62 & $-17.55 * *$ & 16.53 \\
\hline $\mathrm{R}^{2}$ & & \multicolumn{2}{|c|}{0.55} & \multicolumn{2}{|c|}{0.68} \\
\hline LR statistic & & \multicolumn{2}{|c|}{47.41} & \multicolumn{2}{|c|}{55.40} \\
\hline Prob (LR statistic) & & \multicolumn{2}{|c|}{0.000000} & \multicolumn{2}{|c|}{0.000000} \\
\hline
\end{tabular}

Note: This table presents the results for sub-sample II which covers the period from 2012 to 2015.VSA = voluntary sustainability assurance; $C E P$ $=$ corporate environmental performance $\left(\mathrm{CEP}_{1}=\right.$ the ratio of total $\mathrm{GHG}$ emitted to total revenue; $\mathrm{CEP}_{2}=$ the ratio of total water consumed to total revenue; $\mathrm{CEP}_{3}=$ the ratio of total waste produced to total revenue); FSIZE = firm size; $P R O F=$ profitability; $L E V=$ leverage; $I N D=$ industry; $A S S T \_A G E=$ asset age. $* * * \mathrm{p}<0.01 ; * * \mathrm{p}<0.05 ; * \mathrm{p}<0.10$. 